\title{
ДЕФИЦИТ ГУМУСА В ПОЧВЕ КАК ПРАКТИЧЕСКАЯ ПРОБЛЕМА ПОЛУЧЕНИЯ ПЛАНИРУЕМОГО КОЛИЧЕСТВА ПРОДУКЦИИ ПОЛЕВОДСТВА В РЕГИОНАХ ЛЕСОСТЕПИ И СТЕПИ ЕВРОПЕЙСКОЙ ТЕРРИТОРИИ РОССИИ
}

\author{
СВИРИДОВ В.И.,
} доктор сельскохозяйственных наук, ведущий научный сотрудник ФГБНУ «Курский федеральный аграрный научный центр», kafdgmu@ yandex.ru.

Реферат. Проведенный автором на основе областных статистических сборников анализ динамики структуры посевных площадей по подзонам лесостепной и степной зон европейской части Российской Федерации за 2010-2018 гг. показал, что по мере вхождения России в мировой аграрный рынок сельхозтоваропроизводители все больше концентрируют свое внимание на выращивании лишь тех культур, которые гарантируют достижение наивысших экономических результатов: из группы зерновых это озимая пшеница, ячмень, кукуруза, из группы технических - подсолнечник, соя, рапс. Отмечается также тенденция устойчивого снижения в лесостепных и степных регионах ЕТР доли многолетних и однолетних трав и чистого пара в общей площади пахотных угодий. С целью оптимизации структуры посевных площадей на основе эколого-экономико-математического моделирования в работе предлагается оценочная шкала сельскохозяйственных культур по балансу гумуса при сложившейся в среднем за 2014-2018 гг. их урожайности в разрезе шести типичных административных регионов. Она свидетельствует о том, что баланс гумуса в почве практически по всем возделываемым культурам является отрицательным с дефицитом в лесостепной зоне от 280 до 920 кг/га в группе зерновых и от 1130 до 2020 кг/га в группе пропашных культур, а в степной зоне - от 450 до 870 и от 1350 до 1860 кг/га, соответственно. Даже многолетние травы, отличающиеся наибольшей способностью накапливать органическое вещество, при фактической их низкой урожайности в большинстве случаев не обеспечивают бездефицитный баланс почвенного гумуса. Безусловно, эти данные, полученные расчетным путем, следует рассматривать как ориентировочные и их целесообразно проверять экспериментально для каждого конкретного региона и соответствующего уровня урожайности выращиваемых культур.

Ключевые слова: европейская территория России (ЕТР), подзоны лесостепи и степи, типичные административные регионы, структура посевных площадей, экономические интересы, экологические требования, урожайность сельскохозяйственных культур, почвенное плодородие, баланс гумуса, оптимизация.

\section{DEFICIT OF HUMUS AS A PRACTICAL PROBLEM OF RECEIVING A PLANNED AMOUNT OF CROP PRODUCTION IN THE FOREST-STEPPE REGIONS AND THE STEPPE OF THE EUROPEAN PART OF RUSSIA}

\section{SVIRIDOV V.I.,}

Doctor of Agricultural sciences, forward researcher of Federal State Budget Scientific Institution «Kursk State Agricultural Scientific Center»; kafdgmu@yandex.ru.

Essay. Carried by an author out the analysis of structural dynamic in the structure of sown areas of subzones of the forest-steppe zone of European part of the Russian Federation for 2010-2018 based on regional statistical compendium showed that as Russia enters the world agricultural market, agricultural producers are increasingly focusing their attention on growing only those cultures that guarantee reaching the highest economical results such as: winter wheat from the grain group, barley, corn, from technical group there are sunflower, soy, rapseed. A steady decline tendency of the share of perennial and annual grasses and clean fallow in the total arable land in forest-steppe and steppe regions of the European territory of Russia should also be noticed. In case of optimization the structure of arable lands there is an estimated scale of agricultural crops based on ecological-economic-mathematical modeling according to the balance of humus with their average yield in 2014-2018 in the context of the above six administrative regions suggested in this paper. It testifies that the balance of humus in the 
soil for almost all cultivated crops is negative with a deficit in the forest-steppe zone from 280 to 920 $\mathrm{kg} / \mathrm{ha}$ in the group of cereals and from 1130 to $2020 \mathrm{~kg} / \mathrm{ha}$ in the group of row crops, and in the steppe zone from 450 to 870 and from 1350 to $1860 \mathrm{~kg} /$ ha, respectively. Even perennial grasses with the greatest ability to accumulate organic matter, with their actual low yield, in most cases, do not provide a non-deficit balance of soil humus. Certainly, this data obtained by calculation should be considered as indicative and it is advisable to check them experimentally for each specific region and the corresponding level of crop yields.

Keywords: european territory of Russia (ETR), sub-zones of forest-steppe and steppe, typical administrative regions, structure of crop areas, economical interests, economical requirements, crop yield, soil fertility, balance of humus, optimization.

Введение. Глобальным воздействием гумуса на комплекс агрономических свойств почвы обусловлена его важнейшая роль в повышении урожайности всех возделываемых культур. Поэтому регулирование гумусного состояния почв в с.-х. производстве является ключевой задачей. Условием сохранения почвенного плодородия и достижения оптимального содержания гумуса в почве является бездефицитный и положительный баланс гумуса [1]. По влиянию на баланс гумуса в почве полевые культуры разделяются на три группы: многолетние травы, однолетние зерновые и зернобобовые культуры, пропашные культуры. Степень положительного влияния многолетних трав в основном обусловлена количеством накапливаемых ими в почве корневых и поверхностных остатков, которое зависит от уровня урожая, почвенно-климатических условий, вида трав и состава травосмесей. Известно, что при одинаковых по весу урожаях после многолетних трав остается органических остатков в 2-4 раза больше, чем после однолетних растений [2].

Соотношение разных культур в структуре посевных площадей определяет совокупное действие их на приходную часть органического вещества. По мере увеличения доли пропашных культур среднегодовое количество поступающих в почву растительных остатков уменьшается, в то время как увеличение площади под многолетними травами, озимыми зерновыми культурами повышает эту величину. Поэтому подбор наиболее оптимальных вариантов состава и чередования культур для конкретных условий необходимо проводить не только по величине хозяйственной продукции, но и по величине возвращаемой части биомассы, что будет способствовать сохранению органического вещества почвы.

Цель работы - выявить сложившиеся тенденции в формировании структуры посевных площадей и их влияние на баланс гумуса в почве в хозяйствах типичных административ- ных регионов, характеризующих условия различных подзон лесостепной и степной зон европейской части России, в период активного вхождения страны в мировой аграрный рынок.

Материалы и методика исследования. Информационной базой исследования послужили данные территориальных органов Федеральной службы государственной статистики за 2010-2018 гг. по областям, входящим в лесостепную и степную зоны ЕТР, а также публикации российских ученых по обсуждаемой теме. В работе применялся абстрактнологический метод исследования с использованием приемов анализа, синтеза и аналогии, индукции и дедукции.

Результаты исследования. $B$ лесостеnную зону серых лесных почв, оподзоленных, выщелоченных и типичных черноземов, преимущественно полуувлажненную с редкими засухами, средне и ниже среднего обеспеченную теплом из всех областных регионов ЕТР целиком входят только Тульская, Орловская, Липецкая, Тамбовская, Курская, Пензенская, Ульяновская области и в преобладающей части - Белгородская область; степная же зона обыкновенных и южных черноземов недостаточно обеспеченная влагой, средне и выше среднего обеспеченная теплом включает большую часть Воронежской, Самарской, Саратовской, Ростовской, Оренбургской областей. Всесторонний анализ научных материалов, характеризующих особенности климата, почвенного покрова, рельефа, размещения и специализации сельского хозяйства [3-10], позволил нам выделить в качестве наиболее представительного региона подзоны северной лесостепи Тульскую область, подзоны типичной лесостепи - Курскую область, подзоны южной лесостепи - Белгородскую область, а в разрезе аналогичных подзон степной зоны Воронежскую, Оренбургскую и Саратовскую области, соответственно. Как свидетельствуют данные таблицы 1 , в регионах лесостепной зоны, например, по мере продвижения с 
севера на юг закономерно изменяются показатели теплообеспеченности (сумма температур выше $+10^{\circ} \mathrm{C}$ повышается от $2050-2300^{\circ}$ в Тульской области до 2250-2500 в Курской и $2500-2800^{\circ}$ в Белгородской областях), влагообеспеченности (показатель атмосферного увлажнения в форме отношения осадков к испаряемости понижается с 0,45-0,60 до 0,38-0,50 и $0,34-0,42$, соответственно), биологической продуктивности земли (климатический индекс биологической продуктивности зональных типов почв в этих областях повышается с 120 до 123-128 баллов при естественном увлажнении и с 120 до 131-146 баллов при оптимальном увлажнении). Подобные тенденции наблюдаются и в названных выше трех административных областях различных подзон европейской степи.

Показанное в таблице 2 распределение пахотных угодий по типам почв в каждом из этих регионов подтверждает выше сделанный вывод о том, что Тульскую область, где преобладают в основном черноземы оподзоленные и выщелоченные и серые лесные почвы, можно считать типичным представителем подзоны северной лесостепи ЕТР; Курскую область преимущественно с черноземами выщелоченными и типичными и серыми лесны- ми почвами - подзоны типичной лесостепи; Белгородскую область с преобладанием черноземов типичных и обыкновенных и серых лесных почв - подзоны южной лесостепи. В пределах степной зоны европейской части России Воронежская область, в структуре почвенного покрова которой 40,5\% пашни приходится на долю черноземов обыкновенных, явственно характеризует условия северной степи; Оренбургская область, имеющая в составе типов почв пахотных угодий 43,8\% черноземов южных - типичной степи; Саратовская область с 30,1\% каштановых почв и $34,4 \%$ черноземов южных и обыкновенных южной степи.

Проведенный на основе областных статистических сборников [11-13] анализ динамики структуры посевных площадей по подзонам лесостепной зоны ETP за 2010-2018 гг. (таблица 3 ) приводит к выводу о том, что по мере вхождения России в мировой аграрный рынок сельхозтоваропроизводители все больше концентрируют свое внимание на выращивании лишь тех культур, которые гарантируют достижение наивысших экономических результатов: из группы зерновых это озимая пшеница, ячмень, кукуруза, из группы технических подсолнечник, соя, рапс.

Таблица 1 - Характеристика природных условий административных областей по подзонам лесостепи и степи ЕТР [3]

\begin{tabular}{|c|c|c|c|c|c|c|}
\hline Показатель & 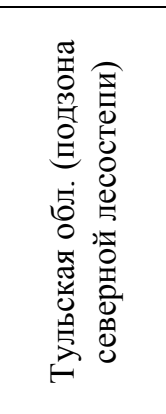 & 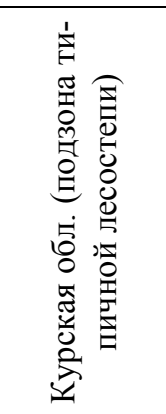 & 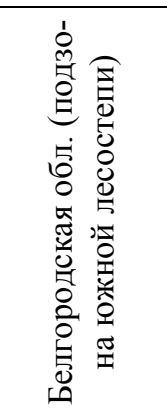 & 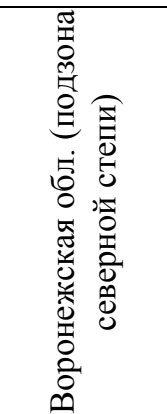 & 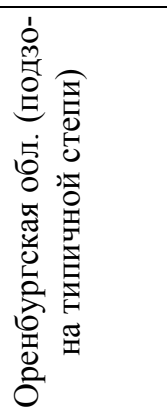 & 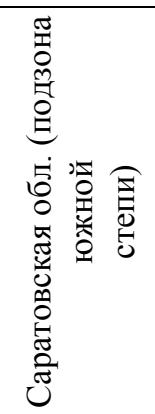 \\
\hline \multicolumn{7}{|l|}{$\begin{array}{l}\text { 1. Распределение территории по при- } \\
\text { родно-сельскохозяйственным зонам, } \\
\%:\end{array}$} \\
\hline \multirow{3}{*}{$\begin{array}{l}\text { лесостепная } \\
\text { степная } \\
\text { сухостепная }\end{array}$} & 100,0 & 100,0 & 83,7 & 47,3 & 9,3 & - \\
\hline & - & - & 16,3 & 52,7 & 81,2 & 60,7 \\
\hline & - & - & - & - & 9,5 & 39,3 \\
\hline 2. Сумма температур $>10^{\circ} \mathrm{C}$ & $2050-2300$ & $2250-2500$ & $2500-2800$ & $2400-2850$ & $2000-2800$ & $2300-3000$ \\
\hline $\begin{array}{l}\text { 3. Показатель атмосферного увлаж- } \\
\text { нения }\end{array}$ & $0,45-0,60$ & $0,38-0,50$ & $0,34-0,42$ & $0,27-0,42$ & $0,15-0,35$ & $0,15-0,35$ \\
\hline $\begin{array}{l}\text { 4. Индекс биологической продук- } \\
\text { тивности земли, балл: } \\
\text { при естественном увлажнении }\end{array}$ & 120 & 123 & 128 & 122 & 91 & 89 \\
\hline при оптимальном увлажнении & 120 & 131 & 146 & 144 & 132 & 146 \\
\hline
\end{tabular}


Таблица 2 - Распределение пахотных угодий по типам почв в хозяйствах всех категорий $(2018$ г.), \%*)

\begin{tabular}{|c|c|c|c|c|c|c|}
\hline Тип почвы & 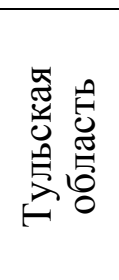 & 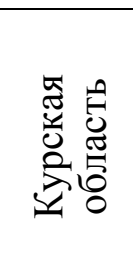 & 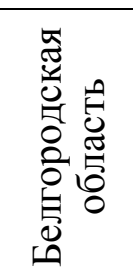 & 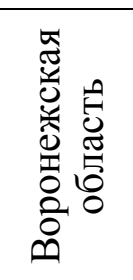 & 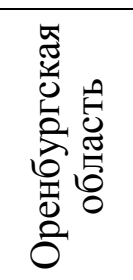 & 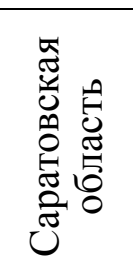 \\
\hline 1. Дерново-подзолистые & 8,1 & - & - & - & - & - \\
\hline 2. Серые лесные & 38,3 & 25,5 & 17,4 & 2,1 & 3,8 & - \\
\hline 3. Черноземы - всего & 53,6 & 74,2 & 80,3 & 93,6 & 79,1 & 67,2 \\
\hline из них: оподзоленные & 22,7 & 5,3 & 12,5 & 4,3 & - & 0,9 \\
\hline выщелоченные & 30,9 & 38,8 & 7,7 & 16,7 & 4,0 & 5,3 \\
\hline типичные & - & 28,4 & 38,9 & 22,1 & 5,1 & 14,2 \\
\hline обыкновенные & - & - & 21,2 & 40,5 & 26,2 & 18,5 \\
\hline Южные & - & - & - & 6,2 & 43,8 & 15,9 \\
\hline 4. Каштановые & - & - & - & - & 16,0 & 30,1 \\
\hline 5. Другие почвы & - & 0,3 & 2,3 & 3,3 & 1,1 & 2,7 \\
\hline Всего пашни в обработке, тыс. га & 965,0 & 1693,5 & 1486,2 & 2779,8 & 5069,2 & 5064,5 \\
\hline
\end{tabular}

*) Рассчитано на основе данных электронных ресурсов [5-10]

Таблица 3 - Структура посевных площадей в хозяйствах административных областей лесостепной зоны ЕТР, \%*)

\begin{tabular}{|c|c|c|c|c|c|c|}
\hline \multirow[t]{2}{*}{ Культура } & \multicolumn{2}{|c|}{ Тульская область } & \multicolumn{2}{|c|}{ Курская область } & \multicolumn{2}{|c|}{$\begin{array}{c}\text { Белгородская } \\
\text { область }\end{array}$} \\
\hline & 2010 г. & 2018 г. & 2010 г. & 2018 г. & 2010 г. & 2018 г. \\
\hline \multirow{6}{*}{$\begin{array}{l}\text { Зерновые и зернобобовые } \\
\text { - всего } \\
\text { из них: пшеница озимая } \\
\text { пшеница яровая } \\
\text { ячмень } \\
\text { зернобобовые } \\
\text { кукуруза на зерно }\end{array}$} & 54,6 & 56,6 & 57,4 & 57,2 & 41,1 & 49,7 \\
\hline & 29,7 & 25,8 & 27,5 & 28,8 & 12,7 & 27,4 \\
\hline & 8,6 & 8,1 & 6,8 & 3,3 & 0,5 & 1,7 \\
\hline & 10,1 & 14,1 & 11,5 & 14,1 & 15,1 & 9,0 \\
\hline & 0,7 & 3,0 & 2,0 & 1,3 & 3,9 & 2,1 \\
\hline & 0,1 & 0,4 & 3,0 & 7,2 & 6,8 & 7,4 \\
\hline \multirow{4}{*}{$\begin{array}{l}\text { Технические - всего } \\
\text { из них: сахарная свекла } \\
\text { подсолнечник } \\
\text { соя }\end{array}$} & 5,8 & 14,7 & 16,0 & 31,8 & 23,8 & 30,3 \\
\hline & 1,1 & 0,8 & 6,4 & 6,4 & 7,1 & 4,1 \\
\hline & 0,3 & 2,2 & 4,9 & 8,9 & 12,7 & 9,8 \\
\hline & 0,8 & 2,5 & 2,5 & 13,1 & 3,8 & 15,6 \\
\hline Картофель и овощи & 4,9 & 3,3 & 4,7 & 2,2 & 4,4 & 3,7 \\
\hline \multirow{3}{*}{$\begin{array}{l}\text { Кормовые - всего } \\
\text { из них: многолетние травы } \\
\text { однолетние травы }\end{array}$} & 13,6 & 12,1 & 8,9 & 4,3 & 14,1 & 11,7 \\
\hline & 8,3 & 7,5 & 2,6 & 2,0 & 5,4 & 6,1 \\
\hline & 2,9 & 2,6 & 3,5 & 1,2 & 3,2 & 1,9 \\
\hline Чистый пар & 21,1 & 13,3 & 13,0 & 4,5 & 16,6 & 4,6 \\
\hline Итого пашни, тыс. га & 940,5 & 965,0 & 1558,0 & 1693,5 & 1491,7 & 1486,2 \\
\hline
\end{tabular}

*) Рассчитано на основе данных статсборников [11-13]

В Тульской области, например, посевы ячменя в общей площади пашни за эти годы увеличились с 10,1 до $14,1 \%$, а технических культур с 5,8 до $14,7 \%$, т.е. в 2,5 раза, при этом подсолнечник в 2018 г занимал $2,2 \%$, соя $-2,5 \%$, рапс же - почти $9 \%$. В Курской области возросла доля озимой пшеницы с 27,5 до
$28,8 \%$, ячменя с 11,5 до $14,1 \%$, кукурузы на зерно с 3,0 до 7,2\%, подсолнечника с 4,9 до $8,9 \%$, а сои - с 2,5 до $13,1 \%$ или более чем в пять раз. В Белгородской области обращает на себя внимание резкое повышение удельного веса озимой пшеницы - с 12,7 до $27,4 \%$ и сои - с 3,8 до 15,6\%. Расширение посевных пло- 
щадей указанных культур в хозяйствах данных административных регионов европейской лесостепи произошло за счет соответствующего сокращения посевов наименее прибыльных товарных (главным образом, крупяных, зернобобовых, сахарной свеклы, картофеля) и кормовых культур (прежде всего, многолетних и однолетних трав, кукурузы на силос и зеленый корм), а также существенного снижения доли чистого пара в составе обрабатываемой пашни (в Тульской области с 21,1 до $13,3 \%$, в Курской - с 13,0 до 4,5\%, в Белгородской - с 16,6 до 4,6\%).

В степной зоне ЕTP (таблица 4) общим для всех ее регионов является чрезвычайно высокий удельный вес в структуре посевных площадей подсолнечника - в 2018 г, например, он составлял $15,7 \%$ в Воронежской области, $18,2 \%$ - в Оренбургской и $24,1 \%$ - в Саратовской областях [14-16], что с точки зрения рационального чередования культур является недопустимым, поскольку возвращать его на прежнее место возделывания рекомендуется не раньше, чем через 7-8 лет. Основной зерновой культурой в Воронежской и Саратовской областях остается пшеница озимая, а в Оренбургской - пшеница яровая. Следует отметить также тенденцию устойчивого снижения в лесостепных и степных регионах ЕТР доли многолетних и однолетних трав и чистого пара в общей площади пахотных угодий.
Смещение акцентов при формировании структуры посевных площадей в сторону расширения посевов коммерчески более выгодных культур, даже в ущерб севооборотным требованиям и воспроизводству почвенного плодородия, подтверждается и данными таблицы 5, характеризующими на примере Курской области динамику экспорта продукции АПК. Так, объемы экспорта пшеницы в среднем за 2015-2018 гг. выросли по сравнению с 2010-2014 гг. в физическом выражении почти в 6 раз, а в стоимостном - в 4 раза, ячменя - в 2,1 и 1,7 раза, а зерна кукурузы - в 66 и 41 раз. Согласно сводной отчетности о финансовоэкономическом состоянии товаропроизводителей АПК Курской области за 2018 г., уровень рентабельности производства и реализации зерна кукурузы составил 40,9\%, пшеницы - 48,8\%, ячменя - 58,4\%, бобов соевых $63,5 \%$, а семян подсолнечника $-74,3 \%$. Вполне очевидно, что при таких показателях экономической эффективности вряд ли можно убедить аграриев в нецелесообразности дальнейшего расширения площади посева той же сои или подсолнечника. Поэтому требуется проведение оценки наряду с экономической также экологической эффективности возделывания как отдельных культур, так и сложившейся в подзонах лесостепи и степи ЕТР структуры посевных площадей в целом.

Таблица 4 - Структура посевных площадей в хозяйствах административных областей степной зоны ЕTР, \%*)

\begin{tabular}{|c|c|c|c|c|c|c|}
\hline \multirow{2}{*}{ Культура } & \multicolumn{2}{|c|}{$\begin{array}{c}\text { Воронежская } \\
\text { область }\end{array}$} & \multicolumn{2}{|c|}{$\begin{array}{c}\text { Оренбургская } \\
\text { область }\end{array}$} & \multicolumn{2}{|c|}{$\begin{array}{c}\text { Саратовская } \\
\text { область }\end{array}$} \\
\hline & 2010 г. & 2018 г. & 2010 г. & 2018 г. & 2010 г. & 2018 г. \\
\hline \multirow{6}{*}{$\begin{array}{l}\text { Зерновые и зернобобовые } \\
\text { - всего } \\
\text { из них: пшеница озимая } \\
\text { пшеница яровая } \\
\text { ячмень } \\
\text { зернобобовые } \\
\quad \text { кукуруза на зерно }\end{array}$} & 43,4 & 53,0 & 57,3 & 53,4 & 46,5 & 47,2 \\
\hline & 22,0 & 28,7 & 7,4 & 7,3 & 21,2 & 20,2 \\
\hline & 2,0 & 1,9 & 28,6 & 25,9 & 4,0 & 5,0 \\
\hline & 13,8 & 10,4 & 9,4 & 10,6 & 8,0 & 7,4 \\
\hline & 1,3 & 1,0 & 0,8 & 2,7 & 2,2 & 7,5 \\
\hline & 3,2 & 10,1 & 0,9 & 0,4 & 0,6 & 1,6 \\
\hline \multirow{4}{*}{$\begin{array}{l}\text { Технические - всего } \\
\text { из них: сахарная свекла } \\
\text { подсолнечник } \\
\text { соя }\end{array}$} & 31,9 & 25,8 & 12,0 & 19,1 & 22,9 & 26,7 \\
\hline & 6,7 & 4,7 & 0,1 & 0,1 & 0,2 & 0,2 \\
\hline & 23,5 & 15,7 & 11,7 & 18,2 & 21,9 & 24,1 \\
\hline & 1,3 & 5,0 & 0,1 & 0,4 & 0,1 & 0,5 \\
\hline Картофель и овощи & 5,3 & 3,2 & 1,1 & 1,2 & 1,1 & 0,7 \\
\hline \multirow{3}{*}{$\begin{array}{c}\text { Кормовые - всего } \\
\text { из них: многолетние травы } \\
\text { однолетние травы }\end{array}$} & 12,9 & 12,3 & 18,5 & 10,1 & 4,9 & 4,0 \\
\hline & 5,3 & 4,9 & 7,2 & 6,0 & 2,8 & 2,2 \\
\hline & 4,0 & 3,7 & 3,4 & 2,7 & 1,5 & 1,3 \\
\hline Чистый пар & 6,5 & 5,7 & 17,1 & 16,2 & 24,6 & 21,4 \\
\hline Итого пашни, тыс. га & 2489,8 & 2731,5 & 4899,3 & 5069,2 & 4780,8 & 5064,5 \\
\hline
\end{tabular}

*) Рассчитано на основе данных статсборников [14-16] 
Таблица 5 - Экспорт продукции АПК Курской области*)

\begin{tabular}{|c|c|c|c|c|c|c|}
\hline \multirow{2}{*}{ Вид продукции } & \multicolumn{2}{|c|}{$\begin{array}{l}\text { В среднем за } \\
2010-2014 \text { гг. }\end{array}$} & \multicolumn{2}{|c|}{$\begin{array}{l}\text { В среднем за } \\
\text { 2015-2018 гг. }\end{array}$} & \multicolumn{2}{|c|}{$\begin{array}{c}\text { 2015-2018гг. к } \\
\text { 2010-2014 гг. }\end{array}$} \\
\hline & тыс. т & тыс. долл. & тыс. т & тыс. долл. & тыс. т & тыс. долл. \\
\hline Злаки - всего & 25,1 & 6246,6 & 179,4 & 30994,6 & в 7,1 раза & в 5 раз \\
\hline $\begin{array}{l}\text { из них: пшеница и } \\
\text { меслин }\end{array}$ & 17,4 & 4356,9 & 100,3 & 17953,5 & в 5,8 раза & в 4,1 раза \\
\hline ячмень & 5,6 & 1327,1 & 11,7 & 2208,4 & в 2,1 раза & в 1,7 раза \\
\hline кукуруза & 1,0 & 259,1 & 66,4 & 10510,0 & в 66,4 раза & в 40,6 раза \\
\hline $\begin{array}{l}\text { Мука пшеничная } \\
\text { или пшенично- } \\
\text { ржаная }\end{array}$ & 2,0 & 588,1 & 2,5 & 625,8 & в 1,2 раза & в 1,1 раза \\
\hline
\end{tabular}

*) Рассчитано на основе данных статистических ежегодников Курской области за 2010-2019 $\Gamma Г$.

Таблица 6 - Баланс гумуса в почве при возделывании полевых культур в хозяйствах административных областей по подзонам лесостепи и степи ЕТР (в среднем за 2014-2018 гг.), \pm $\left.\mathrm{T} / \mathrm{a}^{*}\right)$

\begin{tabular}{|c|c|c|c|c|c|c|}
\hline Культура & 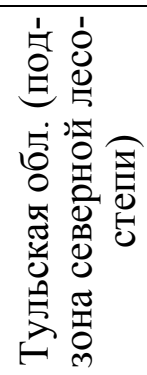 & 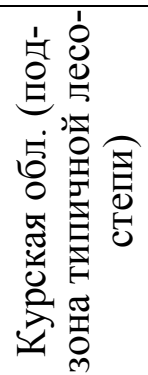 & 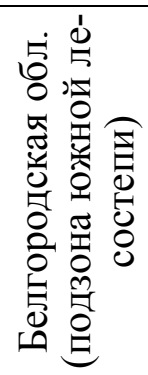 & 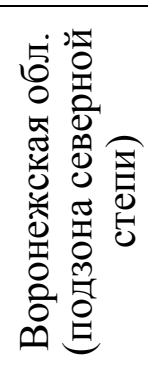 & 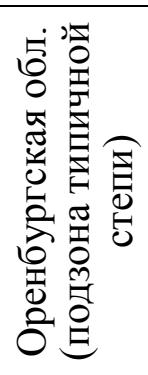 & 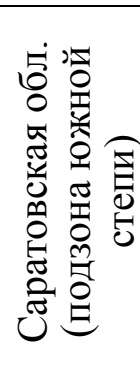 \\
\hline Пшеница озимая & $-0,49$ & $-0,28$ & $-0,33$ & $-0,45$ & $-0,59$ & $-0,47$ \\
\hline Пшеница яровая & $-0,62$ & $-0,42$ & $-0,55$ & $-0,60$ & $-0,78$ & $-0,71$ \\
\hline Рожь озимая & $-0,64$ & $-0,48$ & $-0,54$ & $-0,72$ & $-0,65$ & $-0,62$ \\
\hline Ячмень & $-0,63$ & $-0,44$ & $-0,57$ & $-0,70$ & $-0,78$ & $-0,71$ \\
\hline Овес & $-0,71$ & $-0,60$ & $-0,65$ & $-0,79$ & $-0,78$ & $-0,66$ \\
\hline Просо & $-0,82$ & $-0,73$ & $-0,75$ & $-0,89$ & $-0,83$ & $-0,71$ \\
\hline Гречиха & $-0,92$ & $-0,84$ & $-0,92$ & $-0,92$ & $-0,84$ & $-0,77$ \\
\hline Гopox & $-0,63$ & $-0,65$ & $-0,81$ & $-0,87$ & $-0,80$ & $-0,77$ \\
\hline Кукуруза на зерно & $-1,32$ & $-1,13$ & $-1,37$ & $-1,66$ & $-1,55$ & $-1,35$ \\
\hline Сахарная свекла & $-1,49$ & $-1,54$ & $-1,70$ & $-1,70$ & $-1,56$ & $-1,35$ \\
\hline Подсолнечник на семена & $-1,71$ & $-1,70$ & $-1,85$ & $-1,86$ & $-1,66$ & $-1,59$ \\
\hline Соя & $-0,87$ & $-0,76$ & $-0,84$ & $-0,92$ & $\cdots$ & $-0,68$ \\
\hline Картофель & $-1,69$ & $-1,80$ & $-2,02$ & $-1,96$ & $-1,62$ & $-1,56$ \\
\hline Кукуруза на силос и з/к & $-0,73$ & $-0,66$ & $-0,81$ & $-0,81$ & $-0,83$ & $-0,68$ \\
\hline Корнеплоды кормовые & $-1,63$ & $-1,72$ & $-1,96$ & $-1,84$ & $-1,47$ & $-1,56$ \\
\hline Травы однолетние (сено) & $-0,48$ & $-0,18$ & $-0,31$ & $-0,37$ & $-0,40$ & $-0,27$ \\
\hline $\begin{array}{l}\text { Травы многолетние (се- } \\
\text { но) }\end{array}$ & $-0,25$ & 0,08 & 0,05 & $-0,07$ & $-0,30$ & $-0,16$ \\
\hline Чистый пар & $-2,29$ & $-2,38$ & $-2,60$ & $-2,60$ & $-2,18$ & $-2,08$ \\
\hline
\end{tabular}

*) Рассчитано на основе данных статсборников [11-16] 
С целью оптимизации структуры посевных площадей применительно к условиям лесостепной и степной зон европейской части России на основе эколого-экономико-математического моделирования 「17] нами разработана оценочная шкала сельскохозяйственных культур по балансу гумуса при сложившейся в среднем за 2014-2018 гг. их урожайности в разрезе выделенных выше шести административных регионов (таблица 6). Приведенные данные свидетельствуют о том, что баланс гумуса в почве, определенный как результат сопоставления объема его накопления за счет корневых и пожнивных остатков с потерями гумуса при его минерализации и эрозии почвы [18-19], практически по всем возделываемым культурам является отрицательным с дефицитом в лесостепной зоне от 280 до 920 кг/га в группе зерновых и от 1130 до 2020 кг/га в группе пропашных культур, а в степной зоне - от 450 до 870 и от 1350 до 1860 кг/га, соответственно. Даже многолетние травы, отличающиеся наибольшей способностью накапливать органическое вещество, при фактической их низ- кой урожайности (в пересчете на сено в интервале 0.8-2.9 т/га) в большинстве случаев не обеспечивают бездефицитный баланс почвенного гумуса. Безусловно, эти данные, полученные расчетным путем, следует рассматривать как ориентировочные и их целесообразно проверять экспериментально для каждого конкретного региона и соответствующего уровня урожайности выращиваемых культур.

Вывод. Проведенное исследование показывает, что по мере вхождения России в мировой аграрный рынок отечественные производители сельскохозяйственной продукции все больше концентрируются на выращивании коммерчески более выгодных полевых культур, даже в ущерб севооборотным требованиям и воспроизводству почвенного плодородия. Поэтому требуется проведение оценки наряду с экономической также экологической эффективностью возделывания, как отдельных культур, так и сложившейся в подзонах лесостепи и степи ЕТР структуры посевных площадей в целом.

\section{Список использованных источников}

1. Методические рекомендации по регулированию гумусного состояния черноземных почв Курской области. - Курск: ВНИИЗиЗПЭ, 1990. - 51 с.

2. Дудкин В.М. Севообороты в современном земледелии России.- Курск: Изд-во Курск. гос. с.-х. ак., 1997.- 155 с.

3. Природно - сельскохозяйственное районирование земельного фонда СССР (одобрено Президиумом ВАСХНИЛ и Научно-техническим советом МСХ СССР). - М.: Колос, 1975.-256 c.

4. Агропочвоведение / В.Д. Муха, Н.И. Картамышев, И.С. Кочетов, Д.В. Муха; под ред. В.Д. Мухи.- М.: Колос, 1994.- 528 с.

5. Сельское хозяйство Тульской области [Электронный ресурс]. - Режим доступа: agrien.ru/reg/тульская.html.

6. Сельское хозяйство Курской области [Электронный ресурс]. - Режим доступа: agrien.ru/reg/курская.html.

7. Сельское хозяйство Белгородской области [Электронный ресурс]. - Режим доступа: agrien.ru/reg/белгородская.html.

8. Сельское хозяйство Воронежской области [Электронный ресурс]. - Режим доступа: agrien.ru/reg/воронежская.html.

9. Сельское хозяйство Оренбургской области [Электронный ресурс]. - Режим доступа: agrien.ru/reg/оренбургская.html.

10. Сельское хозяйство Саратовской области [Электронный ресурс]. Режим доступа: agrien.ru/reg/саратовская.html.

11. Тульская область в цифрах. 2018: Крат. Стат. сб./Туластат.- Тула, 2019.- 264 с. $444 \mathrm{c}$.

12. Статистический ежегодник Курской области. 2019: Стат. сб./Курскстат.- Курск, 2019.-

13. Белгородская область в цифрах. 2019: Крат. стат. сб./Белгородстат.- Белгород, 2019.- 252 c.

14. Воронежская область в цифрах. 2019: Крат. стат. сб./Воронежстат.- Воронеж, 2019.- 84 с.

15. Оренбургская область в цифрах. 2019: Крат. стат. сб./Оренбургстат.- Оренбург, 2019.$127 \mathrm{c}$.

16. Саратовская область в цифрах. 2018: Крат. стат. сб./Саратовстат.- Саратов, 2019.- 232 с. 
17. Свиридов В.И. Методологические и методические аспекты проектирования оптимальной структуры посевных площадей в условиях перехода к адаптивно-ландшафтному земледелию // Вестник Курской государственной сельскохозяйственной академии. - 2018. - №2. - С. 4-10.

18. Рекомендации для исследования баланса и трансформации органического вещества при сельскохозяйственном использовании и интенсивном окультуривании почв. - М.: Почвенный институт им. В.В. Докучаева, 1984. - 95 с.

19. Научно-практические основы адаптивно-ландшафтной системы земледелия Курской области. - Курск: ФГБНУ ВНИИЗиЗПЭ ФАНО России, 2017. - 188 с.

\section{Spisok ispol zovanny $x$ istochnikov}

1. Metodicheskie rekomendacii po regulirovaniyu gumusnogo sostoyaniya chernozemny`x pochv Kurskoj oblasti. - Kursk: VNIIZiZPE', 1990. - 51 s.

2. Dudkin V.M. Sevooboroty` v sovremennom zemledelii Rossii.- Kursk: Izd-vo Kursk. gos. s.-X. ak., 1997.- $155 \mathrm{~s}$.

3. Prirodno - sel`skoxozyajstvennoe rajonirovanie zemel’nogo fonda SSSR (odobreno Prezidiumom VASXNIL i Nauchno-texnicheskim sovetom MSX SSSR). - M.: Kolos, 1975.-256 s.

4. Agropochvovedenie / V.D. Muxa, N.I. Kartamy`shev, I.S. Kochetov, D.V. Muxa; pod red. V.D. Muxi.- M.: Kolos, 1994.- 528 s.

5. Sel`skoe xozyajstvo Tul`skoj oblasti [E`lektronny`j resurs]. - Rezhim dostupa: agrien.ru/reg/tul`skaya.html.

6. Sel`skoe xozyajstvo Kurskoj oblasti [E`lektronny`j resurs]. - Rezhim dostupa: agrien.ru/reg/kurskaya.html.

7. Sel`skoe xozyajstvo Belgorodskoj oblasti [E`lektronny`j resurs]. - Rezhim dostupa: agrien.ru/reg/belgorodskaya.html.

8. Sel`skoe xozyajstvo Voronezhskoj oblasti [E`lektronny`j resurs]. - Rezhim dostupa: agrien.ru/reg/voronezhskaya.html.

9. Sel`skoe xozyajstvo Orenburgskoj oblasti [E`lektronny`j resurs]. - Rezhim dostupa: agrien.ru/reg/orenburgskaya.html.

10. Sel'skoe xozyajstvo Saratovskoj oblasti [E`lektronny`j resurs]. Rezhim dostupa: agrien.ru/reg/saratovskaya.html.

11. Tul`skaya oblast` v cifrax. 2018: Krat. Stat. sb./Tulastat.- Tula, 2019.- 264 s.

12. Statisticheskij ezhegodnik Kurskoj oblasti. 2019: Stat. sb./Kurskstat.- Kursk, 2019.- 444 s.

13. Belgorodskaya oblast' v cifrax. 2019: Krat. stat. sb./Belgorodstat.- Belgorod, 2019.- $252 \mathrm{~s}$.

14. Voronezhskaya oblast` v cifrax. 2019: Krat. stat. sb./Voronezhstat.- Voronezh, 2019.- 84 s.

15. Orenburgskaya oblast` v cifrax. 2019: Krat. stat. sb./Orenburgstat.- Orenburg, 2019.- 127 s.

16. Saratovskaya oblast`v cifrax. 2018: Krat. stat. sb./Saratovstat.- Saratov, 2019.- 232 s.

17. Sviridov V.I. Metodologicheskie i metodicheskie aspekty' proektirovaniya optimal'noj struktury` posevny`x ploshhadej $\mathrm{v}$ usloviyax perexoda $\mathrm{k}$ adaptivno-landshaftnomu zemledeliyu // Vestnik Kurskoj gosudarstvennoj sel`skoxozyajstvennoj akademii. - 2018. - №2. - S. 4-10.

18. Rekomendacii dlya issledovaniya balansa i transformacii organicheskogo veshhestva pri sel`skoxozyajstvennom ispol’zovanii i intensivnom okul'turivanii pochv. - M.: Pochvenny`j institut im. V.V. Dokuchaeva, 1984. - 95 s.

19. Nauchno-prakticheskie osnovy`adaptivno-landshaftnoj sistemy`zemledeliya Kurskoj oblasti. Kursk: FGBNU VNIIZiZPE`FANO Rossii, 2017. - 188 s. 